\title{
Agroecology in Canada: Towards an Integration of Agroecological Practice, Movement, and Science
}

\author{
Marney E. Isaac $1,2,3, *$, S. Ryan Isakson ${ }^{2,3}$, Bryan Dale ${ }^{3}$, Charles Z. Levkoe ${ }^{4}$, \\ Sarah K. Hargreaves ${ }^{5}$, V. Ernesto Méndez ${ }^{6}{ }^{\circ}$, Hannah Wittman ${ }^{7}\left(\mathbb{0}\right.$, Colleen Hammelman ${ }^{8}$, \\ Jennifer C. Langill ${ }^{3}{ }^{(0}$, Adam R. Martin ${ }^{1,2}{ }^{\oplus}$, Erin Nelson ${ }^{9}$, Michael Ekers $^{3}$, Kira A. Borden ${ }^{3}{ }^{\circ}$, \\ Stephanie Gagliardi ${ }^{1}$, Serra Buchanan ${ }^{1}$, Sarah Archibald ${ }^{3}$ and Astrid Gálvez Ciani ${ }^{2}$ (D) \\ 1 Department of Physical and Environmental Sciences, University of Toronto Scarborough, Toronto, \\ ON M1C 1A4, Canada; marney.isaac@utoronto.ca (M.E.I); adam.martin@utoronto.ca (A.R.M.); \\ stephanie.gagliardi@utoronto.ca (S.G.); serrawillow.buchanan@mail.utoronto.ca (S.B.) \\ 2 Centre for Critical Development Studies, University of Toronto Scarborough, Toronto, ON M1C 1A4, \\ Canada; risakson@utsc.utoronto.ca (S.R.I.); astrid.galvezciani@mail.utoronto.ca (A.G.C.) \\ 3 Department of Geography and Planning, University of Toronto, Toronto, ON M5S 1A1, Canada; \\ bryan.dale@mail.utoronto.ca (B.D.); jennifer.langill@mail.utoronto.ca (J.C.L.); \\ mekers@utsc.utoronto.ca (M.E.); kira.borden@utoronto.ca (K.A.B.); sarah.archibald@mail.utoronto.ca (S.A.) \\ Department of Health Sciences, Lakehead University, Thunder Bay, ON P7B 5E1, Canada; \\ clevkoe@lakeheadu.ca \\ 5 Ecological Farmers Association of Ontario, Guelph, ON N1H 6J2, Canada; sarah@efao.ca \\ 6 Department of Plant and Soil Science and Environment Program, University of Vermont, Burlington, \\ VT 05405, USA; ernesto.mendez@uvm.edu \\ 7 Faculty of Land and Food Systems, University of British Columbia, Vancouver, BC V6T 1Z4, Canada; \\ hannah.wittman@ubc.ca \\ 8 Department of Geography and Earth Sciences, University of North Carolina at Charlotte, Charlotte, \\ NC 28223, USA; colleen.hammelman@uncc.edu \\ 9 Department of Sociology and Anthropology, University of Guelph, Guelph, ON N1G 2W1, Canada; \\ enelson@uoguelph.ca \\ * Correspondence: marney.isaac@utoronto.ca; Tel.: +1-416-287-7276
}

Received: 6 July 2018; Accepted: 11 September 2018; Published: 15 September 2018

\begin{abstract}
This article surveys the current state of agroecology in Canada, giving particular attention to agroecological practices, the related social movements, and the achievements of agroecological science. In each of these realms, we find that agroecology emerges as a response to the various social and ecological problems associated with the prevailing industrial model of agricultural production that has long been promoted in the country under settler colonialism. Although the prevalence and prominence of agroecology is growing in Canada, its presence is still small and the support for its development is limited. We provide recommendations to achieve a more meaningful integration of agroecology in Canadian food policy and practice.
\end{abstract}

Keywords: agricultural policy; agroecology; Canada; food movements; on-farm practices

\section{Introduction}

Contemporary interest in agroecology has emerged in response to evidence of widespread problems associated with the industrial model of agricultural production [1-3]. While the industrial model may increase short-term yields of targeted crops in certain geographies and climatic zones, it is also increasingly linked to a number of global environmental problems that compromise the ecological foundations of food systems. These include soil degradation, the depletion and contamination of 
water, the detrimental effects of pesticides on human health, the emission of greenhouse gases, and the loss of genetic resources [4-6].

The processes associated with the biological homogenization, including the adoption of monocultures, and the industrialization of agrarian landscapes have also contributed to a new array of social problems, including widespread and growing inequality, financial indebtedness, and the loss of farmer knowledge, all while increasing the power of transnational agrifood corporations [7-9]. In addition, the industrial agrifood system often constrains farmer autonomy and has negative impacts on the wellbeing of agricultural producers and farmworkers [9-12]. Upstream, legal decisions supporting the rights of commercial plant breeders and a corresponding raft of mergers and acquisitions among seed and agrichemical companies over the past three decades have significantly reduced the number of technologies available to farmers while subjecting them to price discrimination [13-17]. Many farmers are also feeling the pinch downstream, as mergers and acquisitions among commodity buyers and retail outlets, combined with the dismantling of commodity trade and marketing boards in many countries, including Canada, have contributed to farmers' declining market power and their ability to negotiate favorable prices [15,17-19].

Caught in a squeeze of rising input costs and declining or stagnant farm gate prices, farmers throughout the world are frequently faced with rising levels of debt, poverty, hunger, environmental degradation, and, more generally, agrarian distress. To disrupt and develop diverse pathways of resistance to these challenges, a growing number of farmers, social movement organizations, and institutions are recognizing the potential of agroecology as a prominent component of agricultural production and the food sovereignty movement [20,21]. Agroecology offers both a practical and aspirational approach to addressing these issues-one that encompasses various aspects of alternative agricultural systems thinking, and which aims to support local economies while strengthening biodiversity, resilience, and social justice.

In this paper, we survey emerging expressions of agroecology in Canada, and address the challenges of its adoption in the Canadian context by presenting reflections from an interdisciplinary team of scholars and practitioners. Our analysis focuses upon the three complementary dimensions of agroecology in the current literature, namely agroecology as a practice, movement, and science. We assess these three categories by operationalizing domestic examples and relating our findings to the opportunities and challenges of strengthening agroecology in Canada. A discursive analysis elucidates that agroecology emerges in all three of these realms as a "responsive" approach. That is, in Canada, the framework of agroecology, unlike in regions with a strong history of agroecology (Brazil [22], Central America [23], Cuba [24]), has a genealogy that does not primarily stem from discussions about the revival or reinvigoration of traditional, place-based knowledges and practices (despite several intersections of agroecological discourse with themes related to indigenous food sovereignty, taken up later in this paper). Rather, it is a transformative and science-based movement that aims to radically counter a history of policies, practices, and ideologies that have prioritized maximizing agricultural yields over other socioeconomic, environmental, and biocultural objectives.

\subsection{The Epistemological Plurality of Agroecology}

Agroecology has evolved as a field that focuses on the application of ecological principles to agricultural research and practice [25-27], to an approach that engages the ecology of the entire agrifood system [28], and that seeks broad participation of a diversity of actors and knowledge systems [29]. The science of agroecology is currently focused on testing and characterizing the mechanisms, processes, and socio-ecological dynamics of diversified agricultural systems, but it is often isolated within the viewpoint of Western academia [30,31]. At the same time, farmers' knowledge and practices of agroecological farming offer equally important insights to scientists [32]. Associated social movement efforts play a prominent role in addressing the broader conditions (e.g., public support, policies and programs, land rights) that make agroecology possible in specific localities. Confounding the pluralistic definition of agroecology is an array of terminology; while terms, such as 
'permaculture' and 'biodynamic', are less popular globally than 'organic', all of these approaches are on a trajectory towards, but are not synonymous with, agroecology.

These multi-modal perspectives of agroecology illustrate the different and sometimes competing understandings of "agroecology" as an on-farm practice, "agroecology" as a movement and political tool, and "agroecology" as a science across academic disciplines [2]. This tension, and potential opportunity, sparks a need to address the synergies among different conceptualizations of agroecology among academics, politicians, agricultural producers, and social movement actors. For example, one may ask a direct yet surprisingly complicated question: Why do farmers cultivate biologically complex agroecological systems? Through multiple lenses, responses could include, but are not limited to: (i) To ensure nutrient cycling, yield stability, and ecosystem services [1]; (ii) as an expression of autonomy and bulwark against uncertain and uneven market relations [23,33]; (iii) to carve out alternative agrarian spaces defined by non-commodified exchanges of labour and education [34]; (iv) to counter macro-scale political and economic phenomena and strive for social justice [35]; and/or (v) to improve household and community food security [36-38]. Motivations for engaging with agroecological practices are derived from a range of thematic and methodological approaches, including environmental and biological sciences, political economy, labour, food sovereignty, and justice.

\subsection{The Canadian Context}

While the three main identities of agroecology (a practice, a movement, and a science) have received cursory attention from both a global and developing world perspective [2,39], to date, there remain no multi-disciplinary comprehensive assessments that address these trends in a North American context. Canada remains a significant player in global agriculture; it is the fifth largest exporter in the world, including the largest exporter of dominant crops, such as durum wheat, pulses, and oats. According to national databases, the agriculture and agrifood sector employs 2.3 million Canadians. Yet, policies aimed at significantly expanding agroecological production in Canada would run counter to a long history of governmental support for an export-oriented agriculture that is based on economies of scale, mechanization, standardization [40,41], and the widespread and increasingly intense application of industrial style inputs (Table 1). Since the late 1960s, in particular, the federal government has firmly held such a vision for the agricultural sector, with a continued focus on the expansion of international markets and economic competitiveness [42].

Table 1. Canadian land (ha) under field crops in 2011 and 2016. Also shown are land (ha) and \% of total crop land under commercial fertilization, herbicides, insecticides, fungicides and conventional tillage for 2011 and 2016 as well as the \% increase in land from 2011 to 2016. [Table based upon Statistics Canada data.]

\begin{tabular}{|c|c|c|c|c|c|}
\hline & \multicolumn{2}{|c|}{2011} & \multicolumn{2}{|c|}{2016} & \multirow{2}{*}{$\begin{array}{l}\% \text { increase in } \\
\text { ha }(2011-2016)\end{array}$} \\
\hline & Hectares (1000) & $\begin{array}{l}\text { \% of total } \\
\text { crop land }\end{array}$ & Hectares (1000) & $\begin{array}{l}\% \text { of total } \\
\text { crop land }\end{array}$ & \\
\hline Total land under crops & 35,350 & $100 \%$ & 37,791 & $100 \%$ & $6 \%$ \\
\hline Commercial fertilizer & 24,918 & $72 \%$ & 28,481 & $75 \%$ & $13 \%$ \\
\hline Herbicides & 26,699 & $76 \%$ & 29,318 & $78 \%$ & $9 \%$ \\
\hline Insecticides & 3150 & $9 \%$ & 5193 & $14 \%$ & $39 \%$ \\
\hline Fungicides & 5511 & $16 \%$ & 9358 & $25 \%$ & $41 \%$ \\
\hline Conventional tillage & 12,890 & $36 \%$ & 13,539 & $36 \%$ & $5 \%$ \\
\hline
\end{tabular}

Arguably, Canada provides a distinctive context to understand the deployment and constraints of agroecology. Unlike the development of agroecology in many countries as the revitalization of place-based knowledges [43,44], in Canada, agroecology can be framed as a reaction to the environmental degradation caused by a productivist form of agriculture that in fact stretches back to the onset of settler colonialism $[45,46]$. Indeed, a discursive assessment of agroecology in current Canadian practice, movements, and science generally elucidates a "responsive" agricultural approach to a rather 
consolidated history of yield maximization models. In this paper, we focus on illustrating the emerging interactions (both positive and antagonistic) among agroecological practice, movements, and science within the Canadian context. We stress that Indigenous food provisioning practices are tremendously important to food sovereignty struggles in Canada [47], and that the advancement of agroecology in this country will therefore need to address the realities of ongoing settler colonialism and Indigenous dispossession $[48,49]$. This includes an engagement with both the historical trajectories of settler agriculture compromising Indigenous sovereignty [50,51], as well as the current threats to Indigenous foodways due to, for example, development projects, industrial pollution, and treaty violations (where treaties are in place) [52,53]. In this light, it is also important to acknowledge that throughout this paper, we focus exclusively on terrestrial agriculture, as is common in the field of agroecology; however, it must be noted that fisheries, foraging, and other forms of food provisioning practiced by Indigenous peoples are very much aligned with agroecological principles and complementary notions of agricultural bioregionalism [54].

The future of alternative agricultural production in Canada is relevant to not only the security and promotion of sustainable food production at the national level, but also to food production globally. To reflect more on the role of agroecology in the Canadian context, we brought together an interdisciplinary team of scholars and practitioners involved in various dimensions of agroecology. We assess the three themes of agroecology by operationalizing domestic case studies and relate our findings to the opportunities and challenges associated with strengthening agroecology in the context of Canadian policies and practices.

\section{The Scope and Implementation of Agroecological Practices in Canada}

There is no commonly held definition of agroecological practice in Canada. The closest proxy is certified organic production, yet, as we note above, organic production fails to capture multiple dimensions of agroecological practices and motivations. However, the number of Canadian farms cultivating organic products increased 65\% between 2001 and 2016 (see Figure 1 for data on organic production distribution in Canada), which indicates a trend toward increased ecological farming across the country and possibly a transition to the adoption of more ambitious agroecological practices. Within Canada, organic farming in 2001 was concentrated in Saskatchewan (773 farms), Ontario (405), Quebec (372), and British Columbia (319) [55]. While the Census of Agriculture no longer asks farmers to specify which of their products are certified organic [56], in 2006, the majority of farms reporting certified organic products were producing hay or field crops (2462 farms), followed by fruits, vegetables, or greenhouse products (916 farms) [57]. Despite the growth of organic farming in Canada, certified organic products account for no more than $1.9 \%$ of total production. Moreover, the 2006 Census of Agriculture allowed farmers to report selling uncertified organic products, which totaled 11,937 farms [58]. This is indicative of the numerous farms in Canada following organic, ecological, and agroecological practices that remain otherwise unreported. While this question is no longer included in the Census, it is notable that over three times as many farms reported uncertified organic products than those that reported certified organic products. This growth is particularly notable as, simultaneously, the number of farms in Canada continues to decline, having decreased by more than 50,000 between 2001 and 2016. [59-62]. 


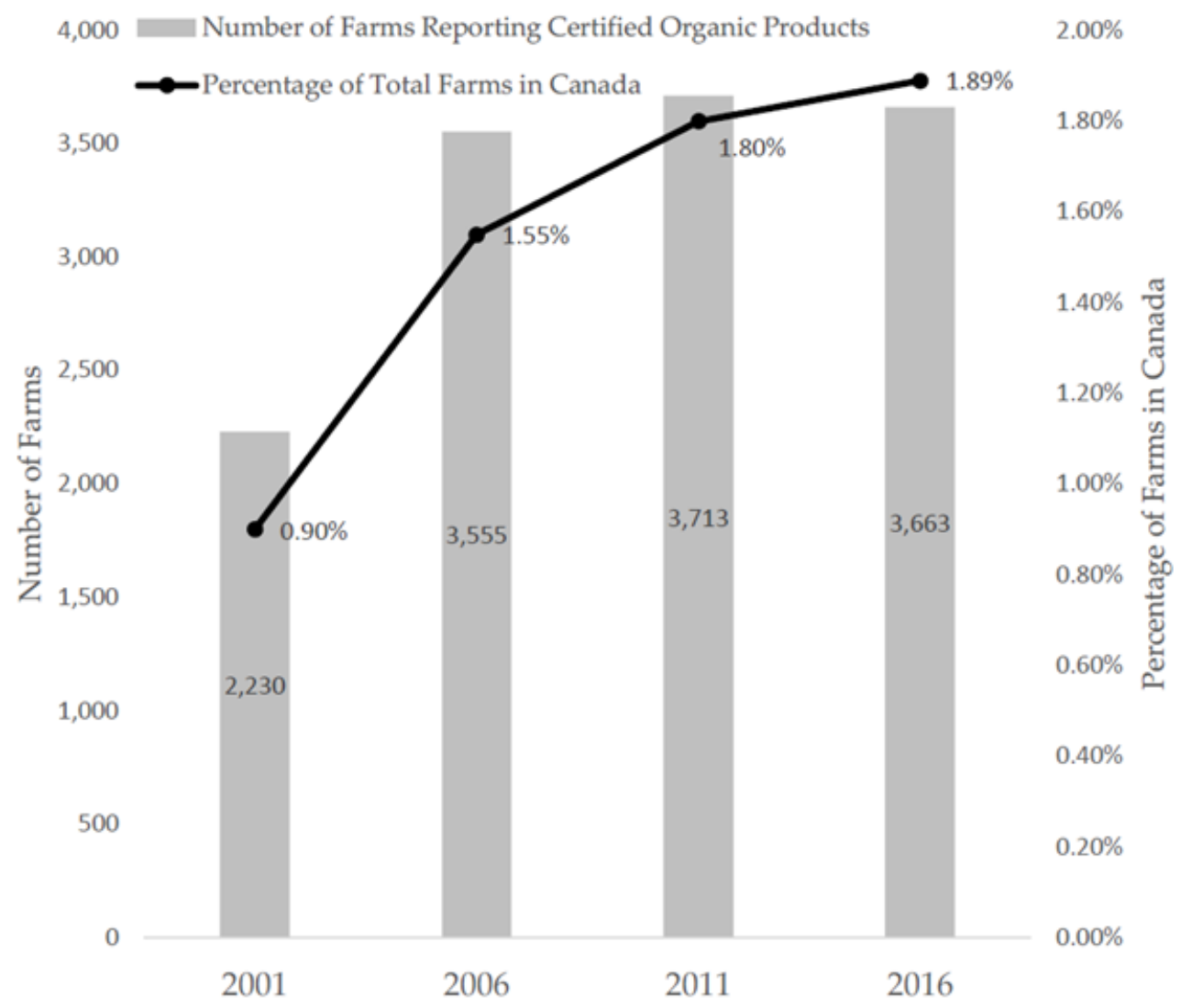

Figure 1. Number and percentage of farms in Canada reporting Certified Organic products (2001-2006). [Figure based upon Statistics Canada data.]

To characterize what we mean by agroecological, we use examples common in Canada, including the integration of crops and livestock and/or by relying solely on organic inputs. In livestock production, the focus is often on pasture-raised animals and, in the case of cattle and other ruminants, employing rotational (multi-paddock) grazing practices as a form of agroecological practice (e.g., Ecological Farmers Association of Ontario Research Library). In plant-based production, many farms move beyond the Canadian organic standards in terms of disease control and fertility amendments by avoiding even the use of 'natural' pesticides that are listed as 'permitted substances,' and by cycling nutrients on-farm (i.e., preparing their own compost or green manure). Farmers tend to emphasize cover cropping, and agroecological practices that further increase diversity, such as extended crop rotations (e.g., Canadian Organic Growers Gaining Ground Handbook). Though less common in Canada, intercropping and agroforestry are gaining ground as a viable agroecological practice to achieve higher soil fertility and moisture availability. Recently in the province of Saskatchewan, the practice of intercropping was adopted on-farm and recognized as a method leading to decreased synthetic inputs and increased water retention at the farm scale-a practice that thus garnered national attention [63]. Even conventional farmers are indicating a desire to adopt practices that support soil health, such as under the auspice of the Innovative Farmers Association of Ontario. Clearly, however, a systematic survey of agroecological practices in Canada is needed.

Given the dramatic decline of extension services in Canada, and especially those geared toward ecologically oriented production [64], knowledge generation and transfer that supports agroecological practices is largely facilitated by non-profit and grassroots organizations (except for a few examples of government support, such as the Agriculture and Agri-Food Canada Environmental Farm Plan, which encourages ecological and organic agriculture). Examples of these non-governmental organizations and initiatives include USC Canada, The Young Agrarians, The Bauta Family Initiative on Canadian Seed Security (facilitated by USC Canada), Quebec's Coopérative pour l'agriculture de proximité 
écologique (CAPÉ) and Réseau des joyeux maraîchers écologiques (RJME), and the Ecological Farmers Association of Ontario (EFAO). (These examples do not include national or regional organic networks, such as the Atlantic Canadian Organic Regional Network (ACORN), which engage in knowledge generation/transfer to varying degrees.) For instance, EFAO, a membership-based not-for-profit organization based in Guelph, Ontario founded in 1979 by farmers, for farmers, supports a community of ecological producers through education, farmer-to-farmer training, and knowledge sharing. EFAO is also active in research, with the start of a farmer-led research program in 2016. The program supports EFAO member-farmers to conduct and share the research they conduct for their farms.

These organizations' programming are typically dependent on short-term and unstable financial support, from both government organizations and private foundations. Given the precarious nature of nonprofit funding and the lack of support for agroecological practices in current federal and sub-national frameworks, the innovators and early adopters of agroecological practices are not well supported. Because of these trends, farmer-to-farmer knowledge sharing-a key pillar of agroecology-is happening on the margins of mainstream agricultural training. Except for a few examples of agroecological training (for instance, on-farm training through programs, such as Everdale Environmental Learning Centre, EFAO's field days, workshops and Advisory Services, and the British Columbia-based farmer training schools at the University of British Columbia and Kwantlan), very little support exists to organize and sustain efforts in rural agroecological practice, with minimal agroecology policy to encourage such efforts.

The topic of labour is also significant in terms of the potential for agroecological practices to proliferate in Canada. Historically, women and children have provided unpaid labour to Canadian farm operations, but increasingly young women and men are coming from off farms to work on farms in exchange for an education in ecological production methods [65]. Domestic and migrant farm workers represent the final source of labour on many farms, including relatively agroecological operations. Among larger organic farms, it has been especially common for operators to employ migrant workers through the Seasonal Agricultural Worker Program (SAWP), a program that has been in existence since 1966 and that is designed to have workers from Mexico and several Caribbean nations fill labour shortages on various types of agricultural operations [66,67]. Many producers, including some employing migrant workers, are concerned about the precarity of migrant workers and the lack of citizenship rights they are afforded [68,69]. In the best cases, producers employing migrant workers on agroecological operations through guest worker programs have emerged as strong advocates for migrant workers' rights, calling for paths to citizenship.

Even though state-led support for agroecological practices is minimal, agroecology is gaining traction in several new arenas, including among urban growers [70]. Despite the relatively short growing season, agricultural production is widespread in Canadian cities. A 2002 poll found that $44 \%$ of households in Vancouver and $40 \%$ of those in Toronto had at least one member who grows food [71]. One might imagine that this involvement has increased with the growing public interest in food over the past decade, and there is reason to believe that many of these growers are partial to practices in line with agroecology.

Recent research has highlighted the viability of agroecology in urban and peri-urban contexts and its potential to advance environmental objectives [72,73] and promote food justice [74,75]. To date, no studies have explicitly researched agroecology in Canadian cities. Yet, community gardening in Toronto and Montreal has been credited with advancing a number of social and environmental objectives, including improving marginalized city dwellers' access to nutritious and culturally appropriate food, fostering community solidarity and development, and promoting democratic practices and activism among previously excluded populations [76,77]. In Toronto, the Toronto Urban Growers (TUG), a network of urban agriculture advocates and practitioners, released a set of indicators by which to assess the effectiveness of urban agriculture projects. Among the 30 indicators identified, seven addressed environmental concerns, including planting practices that lead to improved soil, water, and air quality; storm-water management and water conservation; and increased biodiversity. Another 
seven indicators focus upon social objectives, such as equality and the inclusion of marginalized populations, social cohesion, and collaboration with other social organizations [78].

Urban growers' interest in environmentally sustainable and socially just food is also mirrored in consumer demand. This is demonstrated in the dramatic growth of Community Supported Agriculture (CSA) initiatives and with the rising popularity and activity at farmers' markets over recent decades [79]. In three case studies of farmers' markets in Ontario, it was found that the most common reasons for attending were the freshness and quality of the food, supporting local farmers, environmental concerns, and sociocultural interaction [79-81]. Although some research has found that consumers rarely discuss production systems with producers [80,81], these urban consumers increasingly express an interest in purchasing ecologically produced goods [79].

Initiatives in urban environments, such as the Toronto's Black Creek Community Farm and The Stop; Thunder Bay's Roots to Harvest's urban farm, garden, and edible food forest; Vancouver's Inner City Farms; and Montreal's Lufa Farms, all recognize the mounting consumer interest in purchasing foods grown agroecologically and locally grown by farmers with whom they can interact (see [82]). This phenomenon suggests that the expansion of agroecology in Canada is not only contingent upon 'production practices', but also the social relations of exchange. The implementation of agroecology must consider the entire food system, including consumption and consumer integration, and the broader political and economic systems in which food provisioning occurs [83-85]. As we discuss in the following section, an emerging food movement in Canada aims to do just that.

\section{Agroecology and Canadian Food Movements}

Agroecological principles have been adopted by food movements around the world in recent decades, with many proponents linking agroecology to struggles for food sovereignty $[21,35,86]$. Food sovereignty can be described as "the right of all people to healthy, culturally appropriate food produced through ecologically sound and sustainable methods, and their right to define their own agricultural systems" [87]. The food sovereignty movement's origins can be traced, in part, to the work of the transnational peasant movement, La Vía Campesina, and its efforts in the early 1990s to help marginalized agricultural producers across the globe to resist the industrial food system by placing control of food production, distribution, and consumption within local communities $[88,89]$. Food sovereignty advocates for the fight for keeping food production under the control of peasants and small-scale sustainable fisherfolk and farmers through the construction of agroecological alternatives that meet their needs [90].

The discursive entry of agroecology to Canada's food movement came via the food sovereignty movement. At local, regional, and national levels, organizations of food producers have embraced the ideals of agroecology, if not necessarily the term. Their combined efforts are working to coalesce Canada's agroecological food producers and their allies into a veritable social movement. At the national level, some of these organizations include the National Farmers Union, Food Secure Canada, USC Canada, and Inter Pares, while Union Paysanne is promoting agroecology in Quebec (especially by way of the 'Centre Paysan', Canada's only peasant-led and La Vía Campesina-recognized agroecology school). Most of these organizations have developed partnerships across the globe, including close ties with other food sovereignty proponents.

Complementing these national initiatives, there are also many regional organizations and individual farms within Canada that have adopted agroecology as part of a food sovereignty approach. For example, in Atlantic Canada, one of the primary organizations working to promote sustainable agricultural systems is the Atlantic Canadian Organic Regional Network (ACORN). Founded in 2000, ACORN is a membership-based non-profit that focuses specifically on supporting the certified organic sector. It provides networking services and engages in education and promotional work. ACORN is also heavily involved in fostering seed security-one of the cornerstones of agroecology—and collaborates with the nation-wide Bauta Family Initiative on Canadian Seed Security to deliver its programming in the Atlantic provinces. This work includes partnering with the Dalhousie University 
Faculty of Agriculture and Seeds of Diversity Canada to run a regional seed bank. The organization also runs an annual conference and trade show that brings together ecologically minded producers and consumers from across the region.

Though more prominent in an international context, urban food movements that embrace agroecology as a base principle are starting to take hold in Canadian cities. Several urban agriculture initiatives in Toronto engage with newcomer and Indigenous communities to put their agricultural knowledge to work in fostering ecologically sound growing practices. Similarly, Ottawa's Just Food, while initially a grassroots non-profit addressing urban hunger, today supports an urban farm that specifically incorporates agroecological practices. Urban residents and groups, especially urban growers utilizing agroecological science, increasingly fight for their right to shape food production, distribution, and consumption in their communities [91]. Accordingly, in these urban areas, agroecological concepts can also be found in other movements around food justice, community food security, and slow food (see [28,92]).

At the same time, there are also risks associated with the popularization of agroecological practices and discourses. La Vía Campesina and their allies are particularly alert to the possibility of the term 'agroecology' being equated with large-scale monocultural approaches to growing organic food, or with trends, such as 'climate-smart agriculture' and 'sustainable intensification' [93]. This notion that agroecology is at risk of being co-opted has in fact been raised by others in recent years (see [94]). To counter the potential of co-optation, groups have even begun to specify that they are advocating for an explicitly political 'peasant' agroecology that challenges unequal power relations in the food system [93,94]; and, significantly, social movements adopting agroecology have used it as a frame to articulate resistance against the dominant capitalist logic [95].

\section{The Science of Agroecology and the Canadian Scientific Research Agenda}

In general, prevailing themes of contemporary agricultural science focus on maximizing short-term agricultural production and profit, while also exploring how crop production can be more socially and environmentally sustainable [1]. By extension, this dichotomy has come to frame academic debates surrounding agricultural research as a series of trade-offs in policy and practice: Organic vs. conventional forms of production [96], intensification vs. extensification [97], and provisioning of multiple ecosystem services vs. yield maximization [98]. As a scientific discipline, agroecology is central in such debates, being widely viewed as a branch of agricultural sciences and ecology that addresses the central question: Can the diversification of agricultural systems enhance the provisioning of multiple beneficial agroecosystem functions, including food production, while simultaneously mitigating the negative environmental and social externalities associated with the industrial model of intensified agriculture [1,99-101]?

To answer this question, the science of agroecology draws on multiple disciplines to evaluate how on-farm diversity influences multiple interacting agroecological functions, including crop responses to climate change (e.g., [102]); on-farm carbon sequestration and agricultural contributions to anthropogenic greenhouse gas emission (e.g., [103]); biogeochemical and water cycling (e.g., [104]); biodiversity conservation and habitat provisioning (e.g., [100]); and the maintenance of complex trophic interactions (e.g., [105]); as well as improved food security and farmer livelihoods (e.g., [34,106]).

Underpinning the majority of agroecological research is a general hypothesis of a positive relationship between biodiversity in agricultural systems and the rate of ecosystem service provisioning [99]. Indeed, this expectation forms the basis of essentially all agroecological research that either explores the ecological, environmental, and socio-economic benefits associated with increasing diversity in agricultural systems, or highlights the negative consequences of reduced biodiversity at the level of the farm through to global scales. Agroecological research tends to evaluate hypothesized enhancements in agroecosystem function between biologically diverse systems and monoculture, and observed differences are then often explained based on long-standing ecological principles, such as niche partitioning, facilitation, and competition $[107,108]$. In Canada, contemporary themes for 
agroecological scientific research fall, arguably, into two categories: (i) Studies on productivity, and productivity comparisons between agroecological and conventional systems (e.g., [109]); and (ii) studies on the environmental services (and disservices) conferred by the adoption of agroecological practices (e.g., [110]).

Other threads of agroecological research have tied the ecological basis of agroecology to rural sociology and agrarian studies [111], as well as political ecology [112]. Much of this work examines how agroecology can engage and transform inequitable power and epistemological dynamics in the current agrifood system. This effort to become more transdisciplinary (i.e., crossing academic disciplines, but also knowledge systems) can be seen as a strength by some, and a weakness by others [27], but it is a crucial component in an attempt to coalesce the science, movement, and practice dimensions of agroecology.

In general terms, governments are more inclined to fund research on conventional agricultural practices than on interdisciplinary agroecology and diversified farming. Research shows that in the United States, only 10\% of the Department of Agriculture's 2014 budget for "Research, Extension, and Economics" was directed toward research projects focusing on sustainable agriculture, a very conservative estimate for agroecology in terms of representing ambitious and/or transformative agroecological practices [113]. Similarly, in the UK, research has found that UK aid funding for agroecological projects is less than $5 \%$ of all agricultural aid funding [114].

To date, no such numbers have been published for Canadian research institutions. While a comprehensive analysis, such as that of [113], is beyond the scope of this paper, the awards database of the Natural Sciences and Engineering Research Council of Canada (NSERC) provides some insights into how agroecology factors into Canadian research priorities. The NSERC Discovery Program represents, arguably, Canada's premiere long-term (i.e., five-year) research funding program. In 2016-17, 9725 projects were awarded in total, with 443 grants awarded under this program that include "agri" in the title or keywords, totaling some CAD \$15.6 million in funding or about $4.75 \%$ of the total NSERC Discovery funding for that granting period. Of these, only ten funded projects, totaling CAD $\$ 343,500$, focus on linkages between biodiversity, agroecosystem management, and agroecological functioning. There are certainly other funded research programs with clear applications for agroecological sciences and management, such as research into crop improvement or remote sensing of agricultural systems. However, explicit research on intercropping, or any other interpretations of agroecological science common in the literature [37], do not factor prominently in the current Canadian science funding landscape.

In Canada, social science research is supported by the Social Sciences and Humanities Research Council (SSHRC), including through the Insight Grants and Insight Development Grants, which support long-term (two to five year) research projects. Data from the SSHRC funding database suggests that, as compared to 2008-09, monetary allocation to agroecological research has nearly doubled over the past 10 years. Specifically, in 2008-09 research projects containing the search terms "agr*" and/or "food" were allocated CAD $\$ 994,883$ or $1.3 \%$ of the total amount disbursed by these SSHRC programs. In comparison, $2.2 \%$ of the total monetary awards from these same programs, totaling CAD \$2.1 million, were allocated to agroecology-related research programs in 2016-17. This limited financial support may be reflective of the small, albeit growing, presence of agroecology on Canadian farms.

\section{The State of Canadian Policy on Agroecology}

Agroecology remains on the fringes of Canadian policy at the government level. While scientific researchers working with Agriculture and Agri-Food Canada (AAFC) have called for a greater exploration of agroecology in Canadian production systems [115], current policy frameworks do not use the term, agroecology, explicitly. As such, existing policies may support climate change mitigation, conservation, or organic production, but they fail to cover the full scope of agroecology's multiple dimensions. For example, federal policy frameworks, such as Growing Forward 2, have highlighted some prioritization of industry-supported research and development aligned with organic practices 
through the Organic Science Clusters. At the provincial level, voluntary initiatives, such as the Species at Risk Farm Incentive Program and the Species at Risk Partnerships on Agricultural Land Program in Ontario, offer cost-sharing opportunities for farmers to engage in sustainable agricultural production and conservation practices. Additionally, Quebec uniquely offers marginal financial support (up to CAD $\$ 20,000)$ for farmers to transition to organic production [116]. Yet, these government initiatives do not explicitly address agroecology. For instance, through its Next Agricultural Policy Framework, the AAFC has prioritized the mitigation of greenhouse gas emissions and "innovative approaches to address agri-environmental issues" at provincial, territorial, and regional scales [42], providing a potential avenue to integrate agroecological principles into policy.

There are critical challenges to the widespread adoption of agroecology policies in Canada. First and foremost, among these challenges is the state's attachment to modernist values and its perpetuation of settler colonial practices. Since the late 1960s, in particular, the federal government has firmly held a yield-maximization, productivist, and export-oriented vision for the agricultural sector. The current Canadian Agricultural Policy Framework continues to focus on the expansion of international markets and economic competitiveness [42]. Beyond the pressures towards industrialized export-driven agriculture, other influential aspects of Canada's current agricultural policy scenarios can dissuade agroecological production. As an important example, supply management-which aims to protect farm revenues by coordinating the production of dairy, eggs, chickens, and turkeys through the assignment of limited quotas for each sector-features specific policies that may favour large producers at the expense of new and relatively small farmers $[117,118]$. Over the years, the quota system has made it nearly impossible for new entrants to be able to afford the start-up costs associated with launching a business in these sectors. Additionally, this system makes the integration of crops and livestock a major challenge for growers. High minimum thresholds required to hold quota result in the need for large investment in a single sector, while low exemption thresholds for farmers to engage in these sectors without holding quota make it unlikely for diverse farm operations to be profitable. However, Ontario's Artisanal Chicken Program is a notable exception. By allowing small-scale producers to enter niche markets, it offers a useful example of how to include diversified and smaller-acreage farmers in a supply management system that is generally biased towards heavily capitalized farms $[118,119]$. Thus, while supply management may ultimately align with the goals of Canada's food sovereignty proponents, substantial policy reforms would be needed for it to contribute to an agroecological food production system.

Beyond state-led processes, there have been a number of efforts to engage farmers and other food systems advocates in policy-making as part of civil society engagement initiatives. Building on the work of [120] in the late 1970s that mobilized a diverse range of actors to critically reflect on corporate power in the food system, the People's Food Policy (PFP) project more recently aimed to establish a pan-Canadian food policy proposal rooted in food sovereignty principles [121]. Launched in 2008, the PFP engaged over 3500 Canadians and Indigenous people in conversations about ways to transform the dominant food system. The project led to the release of a cumulative report, Resetting the Table: A People's Food Policy for Canada [122], which highlighted the top policy priorities and a broader vision for a radically transformed, and substantially more democratic, food system. Although it only mentioned agroecology by name in passing, the PFP explicitly called for integrated ecological systems that include diverse forms of learning and practice (e.g., science and technology, and Indigenous and farmer knowledge); open, democratic, and transparent governance processes; and a connecting of place-based experiences to the growing global food sovereignty movement. These are well aligned with agroecology's key principles [2]. Adopted by Food Secure Canada (FSC), the PFP gained widespread international interest, and its processes of citizen-based policy engagement were adopted by a number of movements in other places (e.g., Australia in 2013 and the United Kingdom in 2017).

In May 2017, when the Minister of Agriculture and Agri-Food Canada launched consultations to inform a national food policy for Canada, FSC coordinated a diverse group of social, ecological, and economic advocates, who brought their voices together on a number of key issues fundamental 
for future food systems. The hope was that the national food policy for Canada could finally address the fractured, isolated, and often contradictory policies that structure the country's dominant food system. This included a critique that the federal government's proposed framework ignored the view that food production was part of an interconnected and interdependent web of human and ecological processes, as the framework instead focused on conservation (wherein nature is often perceived as distinct from agricultural production), increased production, and food affordability. Working with a range of individuals, organizations, and networks across Canada's food movements, FSC compiled a set of key recommendations rooted in an integrated food systems perspective, reconciliation with Indigenous peoples, the right to food, and adaptive and socially innovative solutions that would combine technology, science, and community-based knowledge. The FSC (2017) report [123] states that, "Over the long term, we should strive towards a process that will lead to the application of the principles of food sovereignty, which has, at its heart, reclaiming public decision-making power in the food system." Much of this work has built on social movements' efforts to make agroecology and food sovereignty a core part of both short-term tactical and campaign-based efforts, and a longer-term strategic vision.

\section{Conclusions}

In this paper, we present, from the perspective of the Canadian context, (i) the current practices of agroecology and other non-industrialized forms of agriculture on farms, (ii) social movements connected to agroecology, (iii) the science of agroecology and its role in research agendas, and, finally, (iv) the policy landscape (or the lack of it) on agroecology. We illustrate that agroecology in Canada is emerging in a number of dimensions and that efforts to expand and formalize it have been largely led by non-state actors and initiatives. However, these efforts are frequently disjointed, are commonly precarious and underfunded, and are paired with minimal, or often restrictive, government policy. Furthermore, Canada is not unique in that agroecology has the potential to be co-opted as exclusively a set of technologies for production, such as the federal industry aligned Growing Forward 2 framework, rather than being taken up as a form of resistance against the dominant food production system that is environmentally destructive and exacerbates socio-economic inequalities.

Unlike other contexts, wherein the recent growth of agroecology can be understood as a resurgence of place-based knowledges, particularly given its historical de-development and exclusion from dominant models of agricultural production and land use practices, agroecology in Canada is distinctive as a direct response to the degradation caused by a productivist approach that stretches back to the earliest forms of settler colonial agriculture $[45,48]$. In Canada, the full-scale industrial model was deployed in full effect following the Second World War, and emerging agroecological efforts are responses to this particular prevailing production; however, the science, practice, and movement associated with agroecology will need to be informed by Indigenous food sovereignty. In Canada, agroecology offers a mode of production that can enhance yield stability, create autonomy against uncertain and uneven market relations, carve out alternative agrarian spaces to counter macro-scale political and economic phenomena, and improve household and community food security. Specifically, developing agroecology in the Canadian context should aim to re-write agricultural science and technology with due regard to traditional Indigenous knowledge systems; the creation of alternative agricultural practices should take place alongside sustainable food provisioning practices that include fishing, gathering, and hunting; and, finally, the movement for agroecology will need to address key issues, such as land access and food distribution, while simultaneously seeking to rectify the relevant injustices that continue to be perpetuated against Indigenous peoples.

As we have highlighted, there is generally a broad enthusiasm for agroecology among Canadian agricultural producers, farmers' organizations, and other food system actors. Yet, in this context, a concerted effort is needed to merge Canada's disparate agroecological practices, movements, and science, as has recently been noted in Europe [124]. For agroecology to achieve the political, environmental, and socioeconomic transformations envisioned by its various promoters, alliances 
between farmers and non-farmers and between urban and rural stakeholders, and food justice organizations will be necessary in terms of generating popular pressure to change policies and approaches to food system governance in Canada. A movement for agroecology will need to support existing prefigurative approaches to agricultural production, while pushing for these to be replicated and scaled out-an effort that will undoubtedly entail confronting the political economic realities of a system that currently perpetuates labour injustices, corporate consolidation, land speculation, and market-based models that preclude poor people from accessing sustainably produced food.

Funding and support for farmer-led research is also essential. More comprehensive farmer-research collaborations will be necessary, along with increased recognition of existing practices, knowledge, and farmer-to-farmer networks. Similarly, the scientific community will greatly benefit from funding for research on the agroecology of fisheries, and for an agroecology that is informed by Indigenous food systems. Canadian agricultural policy is seemingly shortsighted, particularly in comparison to other countries that are actively integrating agroecology into regulatory frameworks (e.g., Brazil, Cuba, France, Sweden). While we recognize that the transformative potential of policy alone is limited, agroecology is unlikely to become a fundamental tenet of agriculture in Canada unless policies more effectively integrate practices, movements, and science.

Author Contributions: Conceptualization, M.E.I. and S.R.I.; Investigation, Writing-Review \& Editing, M.E.I., S.R.I., B.D., C.Z.L., S.K.H., V.E.M., H.W., C.H., J.C.L., A.R.M., E.N., M.E., K.A.B., S.G., S.B., S.A., A.G.C.; Funding Acquisition, M.E.I. and S.R.I.

Acknowledgments: The authors would like to acknowledge three anonymous journal reviewers for their comments on the manuscript. The authors would like to thank the University of Toronto Scarborough (UTSC) Vice-Principal Research Office Working Group Fund for providing financial support to the UTSC Agroecology Research workshop at which original ideas for this paper were discussed. This work was also supported by the Canada Research Chair program to M.E.I.

Conflicts of Interest: The authors declare no conflict of interest.

\section{References}

1. Tomich, T.P.; Brodt, S.; Ferris, H.; Galt, R.; Horwath, W.R.; Kebreab, E.; Leveau, J.H.J.; Liptzin, D.; Lubell, M.; Merel, P.; et al. Agroecology: A Review from a Global-Change Perspective. Annu. Rev. Environ. Resour. 2011, 36, 193-222. [CrossRef]

2. Méndez, V.E.; Bacon, C.M.; Cohen, R. Agroecology as a transdisciplinary, participatory and action-oriented approach. Agroecol. Sustain. Food Syst. 2013, 37, 3-18. [CrossRef]

3. Martin, A.R.; Isaac, M.E. Plant functional traits in agroecosystems: A blueprint for research. J. Appl. Ecol. 2015, 52, 1425-1435. [CrossRef]

4. Tilman, D.; Cassman, K.G.; Matson, P.A.; Naylor, R.; Polasky, S. Agricultural sustainability and intensive production practices. Nature 2002, 418, 671-677. [CrossRef] [PubMed]

5. Sage, C. Environment and Food; Routledge: London, UK; New York, NY, USA, 2011.

6. Mostafalou, S.; Abdollahi, M. Pesticides: An update of human exposure and toxicity. Arch. Toxicol. 2017, 91, 549-599. [CrossRef] [PubMed]

7. Weis, A.J. The Global Food Economy: The Battle for the Future of Farming; Zed Books: London, UK, 2007.

8. Clapp, J.; Fuchs, D.A. (Eds.) Corporate Power in Global Agrifood Governance; MIT Press: Cambridge, MA, USA, 2009.

9. Akram-Lodhi, A.H. Hungry for Change: Farmers, Food Justice and the Agrarian Question; Fernwood Publishing: Halifax, NS, Canada; Kumarian Press: Sterling, VA, USA, 2013.

10. Van der Ploeg, J.D. The New Peasantries: Struggles for Autonomy and Sustainability in an Era of Empire and Globalization; Earthscan: London, UK; Sterling, VA, USA, 2008.

11. Ramey, E. Class, Gender, and the American Family Farm in the 20th Century; Routledge: Abingdon, UK; New York, NY, USA, 2014.

12. Stock, P.V.; Forney, J.; Emery, S.B.; Wittman, H. Neoliberal natures on the farm: Farmer autonomy and cooperation in comparative perspective. J. Rural Stud. 2014, 36, 411-422. [CrossRef]

13. Kloppenburg, J.R. First the Seed: The Political Economy of Plant Biotechnology, 2nd ed.; University of Wisconsin Press: Madison, WI, USA, 2004. 
14. ETC Group. Merge-Santo: New Threat to Food Sovereignty. 2016. Available online: www.etcgroup.org/ content/merge-santo-new-threat-food-sovereignty (accessed on 31 October 2017).

15. Howard, P.H. Concentration and Power in the Food System: Who Controls What We Eat? Bloomsbury Academic: London, UK; New York, NY, USA, 2016.

16. Clapp, J. Bigger Is Not Always Better: The Drivers and Implications of the Recent Agribusiness Megamergers; Working Paper; Global Food Politics Group, University of Waterloo: Waterloo, ON, USA, March 2017.

17. Magnan, A. When Wheat Was King: The Rise and Fall of the Canada-UK Wheat Trade; UBC Press: Vancouver, BC/Toronto, ON, Canada, 2016.

18. Breger-Bush, S. Derivatives and Development: A Political Economy of Global Finance, Farming and Poverty; Palgrave Macmillan: New York, NY, USA, 2012.

19. Fridell, G. Alternative Trade: Legacies for the Future; Fernwood Publishing: Winnipeg, MB, Canada, 2013.

20. Wittman, H.; Desmarais, A.; Wiebe, N. (Eds.) Food Sovereignty: Reconnecting Food, Nature E Community; Fernwood Publishing: Halifax, NS, Canada, 2010.

21. Pimbert, M.P. Food Sovereignty, Agroecology and Biocultural Diversity: Constructing and Contesting Knowledge; Routledge: New York, NY, USA, 2017.

22. Petersen, P.; Mussoi, E.M.; Dal Soglio, F. Institutionalization of the agroecological approach in Brazil: Advances and challenges. Agroecol. Sustain. Food Syst. 2013, 37, 103-114. [CrossRef]

23. Holt-Giménez, E. Campesino a Campesino: Voices from Latin America's Farmer to Farmer Movement for Sustainable Agriculture; Perseus: New York, NY, USA, 2006.

24. Nelson, E.; Scott, S.; Cukier, J.; Galán, Á.L. Institutionalizing agroecology: Successes and challenges in Cuba. Agric. Hum. Values 2009, 26, 233-243. [CrossRef]

25. Altieri, M.A. Agroecology: The science of Sustainable Agriculture; Westview Press: Boulder, CO, USA, 1995.

26. Gliessman, S.R. (Ed.) Agroecology: Researching the Ecological Basis for Sustainable Agriculture; Ecological Series; Springer: New York, NY, USA, 1990; p. 78.

27. Dalgaard, T.; Hutchings, N.J.; Porter, J.R. Agroecology, scaling and interdisciplinarity. Agric. Ecosyst. Environ. 2003, 100, 39-51. [CrossRef]

28. Francis, C.; Lieblein, G.; Gliessman, S.; Breland, T.A.; Creamer, N.; Harwood, R.; Salomonsson, L.; Helenius, J.; Rickerl, D.; Salvador, R.; et al. Agroecology: The ecology of food systems. J. Sustain. Agric. 2003, 22, 99-118. [CrossRef]

29. Méndez, V.E.; Bacon, C.M.; Cohen, R.; Gliessman, S.R. (Eds.) Agroecology: A Transdisciplinary, Participatory and Action-Oriented Approach. In Advances in Agroecology; CRC Press/Taylor and Francis: Boca Raton, FL, USA, 2016.

30. Fernandez, M.; Goodall, K.; Olson, M.; Méndez, E. Agroecology and alternative agri-food movements in the United States: Toward a sustainable agri-food system. Agroecol. Sustain. Food Syst. 2013, 37, 115-126. [CrossRef]

31. Snipstal, B. Repeasantization, agroecology and the tactics of food sovereignty. J. Can. Food Stud. 2015, 2, 164-173. [CrossRef]

32. Isaac, M.E.; Cerda, R.; Rapidel, B.; Martin, A.R.; Dickinson, A.K.; Sibelet, N. Farmer perception and utilization of leaf functional traits in managing agroecosystem. J. Appl. Ecol. 2018, 55, 69-80. [CrossRef]

33. Isakson, S.R. No Hay Ganancia en la Milpa. J. Peasant Stud. 2009, 36, 725-759. [CrossRef]

34. Levkoe, C.Z. Engaging the tensions of ecological internships: Considerations for agroecology and sustainable food systems movements. Agroecol. Sustain. Food Syst. 2018, 42, 242-263. [CrossRef]

35. Rosset, P.M.; Altieri, M.A. Agroecology Science and Politics; Fernwood Publishing: Halifax, NS, Canada, 2017.

36. Amekawa, Y. Agroecology and Sustainable Livelihoods: Towards an Integrated Approach to Rural Development. J. Sustain. Agric. 2011, 35, 118-162. [CrossRef]

37. Isakson, S.R. Market Provisioning and the Conservation of Crop Biodiversity: An Analysis of Peasant Livelihoods and Maize Diversity in the Guatemalan Highlands. World Dev. 2011, 39, 1444-1459. [CrossRef]

38. Morris, K.S.; Méndez, V.E.; Olson, M.B. Los meses flacos': Seasonal food insecurity in a Salvadoran organic coffee cooperative. J. Peasant Stud. 2013, 40, 423-446. [CrossRef]

39. Wezel, A.; Bellon, S.; Doré, T.; Francis, C.; Vallod, D.; David, C. Agronomy for sustainable agriculture. A review. Agron. Sustain. Dev. 2009, 29, 503-515. [CrossRef]

40. Bouchard, R. Plaidoyer Pour une Agriculture Paysanne: Pour la Santé du Monde; Les Éditions Écosociété: Montréal, QC, Canada, 2002. 
41. Qualman, D. Advancing Agriculture by Destroying Farms? The State of Agriculture in Canada. In Food Sovereignty in Canada: Creating Just and Sustainable Food Systems; Desmarais, A.A., Wiebe, N., Wittman, H., Eds.; Fernwood Publishing: Halifax, NS, Canada, 2011.

42. Agriculture and Agri-Food Canada (AAFC). Calgary Statement: Towards the Next Policy Framework. 2016. Available online: http:/ / www.agr.gc.ca/eng/about-us/key-departmental-initiatives/the-canadianagricultural-partnership / calgary-statement-towards-the-next-policy-framework/?id=1468864509649 (accessed on 26 October 2016).

43. Altieri, M.A. Linking ecologists and traditional farmers in the search for sustainable agriculture. Front. Ecol. Environ. 2004, 2, 35-42. [CrossRef]

44. Saylor, C.R.; Alsharif, K.A.; Torres, H. The importance of traditional ecological knowledge in agroecological systems in Peru. Int. J. Biodivers. Sci. Ecosyst. Serv. Manag. 2017, 13, 150-161. [CrossRef]

45. Desmarais, A.; Wittman, H. Farmers, foodies and First Nations: Getting to food sovereignty in Canada. J. Peasant Stud. 2014, 41, 1153-1173. [CrossRef]

46. Grey, S.; Patel, R. Food sovereignty as decolonization: Some contributions from Indigenous movements to food system and development politics. Agric. Hum. Values 2015, 32, 431-444. [CrossRef]

47. Morrison, D. Indigenous Food Sovereignty: A Model for Social Learning. In Food Sovereignty in Canada: Creating Just and Sustainable Food Systems; Wittman, H., Desmarais, A.A., Wiebe, N., Eds.; Fernwood Publishing: Winnipeg, MB, Canada, 2011; pp. 97-113.

48. Kepkiewicz, L. Understanding Food Sovereignty in Canada: Settler Colonialism and Indigenous-Settler Alliances; Public Policies for Food Sovereignty: Social Movements and the State, Desmarais, A.A., Claeys, P., Trauger, A., Eds.; Routledge: New York, NY, USA, 2017; pp. 164-180.

49. Kepkiewicz, L.; Dale, B. Keeping 'our' Land: Property, Agriculture and Tensions between Indigenous and Settler Visions of Food Sovereignty in Canada. J. Peasant Stud. 2018, 1-20. [CrossRef]

50. Carter, S. Lost Harvests: Prairie Indian Reserve Farmers and Government Policy; McGill-Queen's University Press: Montreal, QC, Canada, 1990.

51. Daschuk, J. Clearing the Plains: Disease, Politics of Starvation, and the Loss of Aboriginal Life; University of Regina Press: Regina, SK, Canada, 2013.

52. Coulthard, G.S. Red Skin White Masks: Rejecting the Colonial Politics of Recognition; University of Minnesota Press: Minneapolis, MN, USA, 2014.

53. Pasternak, S. On Jurisdiction and Settler Colonialism: The Algonquins of Barriere Lake against the Federal Land Claims Policy. Unpublished Ph.D. Thesis, University of Toronto, Toronto, ON, Canada, 2013.

54. Knezevic, I.; Blay-Palmer, A.; Levkoe, C.Z.; Mount, P.; Nelson, E. (Eds.) Nourishing Communities: From Fractured Food Systems to Transformative Pathways; Springer: Cham, Switzerland, 2017.

55. Statistics Canada. Table 12.1: Farms Classified by Certified Organic Products Produced, by Province, Census Agriculture Region (CAR) and Census Division (CD), 2001. 2001a. Available online: http:/ /www.statcan.gc. $\mathrm{ca} /$ pub /95f0301x/t/pdf/4198789-eng.pdf (accessed on 21 November 2017).

56. Statistics Canada. The 2016 Census of Agriculture in Detail. 2016a. Available online: http:/ /www23.statcan. gc.ca/imdb-bmdi/document/3438_D3_T9_V1-eng.htm (accessed on 21 November 2017).

57. Statistics Canada. Agriculture Overview, Canada and the Provinces, Table 1.15, Agriculture Overview, Canada and the Provinces-Farms Producing Certified Organic Products, Census Years 2006 and 2001. 2006. Available online: http:/ / www.statcan.gc.ca/pub/95-629-x/1/4123805-eng.htm\#0 (accessed on 21 November 2017).

58. Statistics Canada. Agriculture Overview, Canada and the Provinces, Table 1.16, Agriculture Overview, Canada and the Provinces-Certified, Transitional or Uncertified Organic Products, Census Year 2006. 2006. Available online: http:/ / www.statcan.gc.ca/pub/95-629-x/1/4182377-eng.htm\#0 (accessed on 21 November 2017).

59. Statistics Canada. 2001 Census of Agriculture-Canadian Farm Operations in the 21st Century. 2001b. Available online: http:/ / www.statcan.gc.ca/daily-quotidien/020515/dq020515a-eng.htm (accessed on 21 November 2017).

60. Statistics Canada. Farms, by Farm Type and Province (Census of Agriculture, 2001 and 2006) (Canada). 2006b. Available online: http:/ / www.statcan.gc.ca/tables-tableaux/sum-som/101/cst01/agrc35a-eng.htm (accessed on 21 November 2017). 
61. Statistics Canada. 2011 Census of Agriculture. 2011. Available online: http://www.statcan.gc.ca/dailyquotidien/120510/dq120510a-eng.htm (accessed on 21 November 2017).

62. Statistics Canada. 2016 Census of Agriculture. 2016b. Available online: http://www.statcan.gc.ca/pub/95640-x/95-640-x2016001-eng.htm (accessed on 21 November 2017).

63. Canada's Outstanding Young Farmers. Derek \& Tannis Axten Chosen as Saskatchewan's Outstanding Young Farmers for 2017. Available online: http:/ / oyfcanada.com/language/en/2017/06/25/derek-tannis-axtenchosen-as-saskatchewans-outstanding-young-farmers-for-2017/ (accessed on 31 July 2018).

64. Milburn, L.S.; Mulley, S.J.; Kline, C. The End of the Beginning and the Beginning of the End: The Decline of Public Agricultural Extension in Ontario. J. Ext. 2010, 48, 1-11.

65. Ekers, M.; Levkoe, C. Transformations in Non-Waged Farm Work: From Kinship to Intern and Volunteer Labour. J. Agric. Food Syst. Community Dev. 2016, 6. [CrossRef]

66. Ramsaroop, C.; Wolk, K. Can we achieve racial equity in the food security movement? In The Edible City: Toronto's Food from Farm to Fork; Palassio, C., Wilcox, A., Eds.; Coach House Books: Toronto, ON, Canada, 2009; pp. 252-263.

67. Reid-Musson, E. Grown Close to Home ${ }^{\mathrm{TM}}$ : Migrant Farmworker (Im)mobilities and Unfreedom on Canadian Family Farms. Ann. Am. Assoc. Geogr. 2017, 107, 716-730. [CrossRef]

68. Otero, G.; Preibisch, K. Citizenship and Precarious Labour in Canadian Agriculture; Canadian Centre for Policy Alternatives, 2015. Available online: https://www.policyalternatives.ca/publications/reports/citizenshipand-precarious-labour-canadian-agriculture (accessed on 10 September 2017).

69. Weiler, A.; Otero, G.; Wittman, H. Rock stars and bad apples: Moral economies of alternative food networks and precarious farm work regimes. Antipode 2016, 48, 1140-1162. [CrossRef]

70. RAUF Foundation. Urban Agroecology. Urban Agriculture Magazine. 2017. Available online: https:/ / www. ruaf.org/sites/default/files/RUAF-UAM\%2033_WEB.pdf (accessed on 21 July 2018).

71. McClintock, N. Radical, reformist, and garden-variety neoliberal: Coming to terms with urban agriculture's contradictions. Local Environ. 2014, 19, 147-171. [CrossRef]

72. Vaarst, M.; Escudero, A.G.; Chappell, M.J.; Brinkley, C.; Nijbroek, R.; Arraes, N.A.M.; Andreasen, L.; Gattinger, A.; de Almeida, G.F.; Bossio, D.; et al. Exploring the concept of agroecological food systems in a city-region context. Agroecol. Sustain. Food Syst. 2017, 42, 686-711. [CrossRef]

73. Herrmann, D.; Chuang, W.C.; Schwarz, K.; Bowles, T.; Garmestani, A.; Shuster, W.; Eason, T.; Hopton, M.; Allen, C. Agroecology for the Shrinking City. Sustainability 2018, 10, 675. [CrossRef]

74. Tornaghi, C. Urban Agriculture in the Food-Disabling City: (Re)defining Urban Food Justice, Reimagining a Politics of Empowerment. Antipode 2017, 49, 781-801. [CrossRef]

75. Blecha, J.; Leitner, H. Reimagining the food system, the economy, and urban life: New urban chicken-keepers in US cities. Urban Geogr. 2014, 35, 86-108. [CrossRef]

76. Baker, L.E. Tending cultural landscapes and food citizenship in Toronto's community gardens. Geogr. Rev. 2004, 94, 305-325. [CrossRef]

77. Wakefield, S.; Yeudall, F.; Taron, C.; Reynolds, J.; Skinner, A. Growing urban health: Community gardening in South-East Toronto. Health Promot. Int. 2007, 22, 92-101. [CrossRef] [PubMed]

78. Teitel-Payne, R.; Kuhns, J.; Nasr, J. Indicators for Urban Agriculture in Toronto: A Scoping Analysis; Toronto Urban Growers: Toronto, ON, Canada, 2016.

79. Dodds, R.; Arunsopha, V.; Chin, N.; Le, T.; Maung, S.; Shum, M. Consumer Choice and Farmers' Markets. J. Agric. Environ. Ethics 2016, 27, 397-416. [CrossRef]

80. Feagan, R.; Morris, D.; Krug, K. Niagara Region Farmers' Markets: Local food systems and sustainability considerations. Local Environ. 2004, 9, 235-254. [CrossRef]

81. Smithers, J.; Lamarche, J.; Joseph, A.E. Unpacking the terms of engagement with local food at the Farmers' Market: Insights from Ontario. J. Rural Stud. 2008, 24, 337-350. [CrossRef]

82. Vancouver Urban Farming Society (VUFS). Vancouver Urban Farming Census 2014-2016. 2016. Available online: http:/ / www.urbanfarmers.ca/vancouver-urban-farming-census-2014-to-2016 (accessed on 8 March 2018).

83. Belz, F.M.; Silvertant, S.; Pobisch, J. Consumer Integration in Sustainable Product Innovation Processes. In SCP Cases in the Field of Food, Mobility and Housing, Workshop of the Sustainable Consumption Research Exchange Proceedings; Lahlou, S., Emmert, S., Eds.; Sustainable Consumption Research Exchange: Paris, France, 2007; pp. 131-150. 
84. Lieblein, G.; Breland, T.A.; Østergaard, E.; Salomonsson, L.; Francis, C. Educational Perspectives in Agroecology: Steps on a Dual Learning Ladder toward Responsible Action. N. Am. Coll. Teach. Agric. J. 2007, 51, 37-44. [CrossRef]

85. Meynard, J.M.; Jeuffroy, M.H.; le Bail, M.; Lefèvre, A.; Bagrini, M.B.; Michon, C. Designing coupled innovations for the sustainability transition of agrifood systems. Agric. Syst. 2016, 157, 330-339. [CrossRef]

86. Altieri, M.; Nicholls, C. Scaling up agroecological approaches for food sovereignty in Latin America. Development 2008, 51, 472-480. [CrossRef]

87. Declaration of Nyeleni. 2007. Available online: https://nyeleni.org/IMG/pdf/DeclNyeleni-en.pdf (accessed on 21 September 2018).

88. Desmarais, A. La Via Campesina: Globalization and the Power of Peasants; Fernwood Publishing: Halifax, NS, Canada, 2007.

89. Edelman, M. Food sovereignty: Forgotten genealogies and future regulatory challenges. J. Peasant Stud. 2014, 41, 959-978. [CrossRef]

90. Altieri, M. Agroecology, small farms, and food sovereignty. Mon. Rev. 2009, 61, 102-113. [CrossRef]

91. Block, D.; Chavez, N.; Allen, E.; Ramirez, D. Food sovereignty, urban food access, and food activism: Contemplating the connections through examples from Chicago. Agric. Hum. Values 2012, 29, 203-215. [CrossRef]

92. Peña, D. Farmers feeding families: Agroecology in South Central Los Angeles. Lecture presented to the Environmental Science, Policy, and Management Colloquium; University of California: Berkeley, CA, USA, 10 October 2005.

93. La Vía Campesina. Declaration of the International Forum for Agroecology; Nyéléni, Mali, 2015. Available online: https:/ / viacampesina.org/en/declaration-of-the-international-forum-for-agroecology/ (accessed on 22 September 2017).

94. Holt-Giménez, E.; Altieri, M. Agroecology, Food Sovereignty, and the New Green Revolution. Agroecol. Sustain. Food Syst. 2013, 37, 90-102. [CrossRef]

95. Gliessman, S.R. Agroecology: Growing the roots of resistance. Agroecol. Sustain. Food Syst. 2013, 37, $19-31$. [CrossRef]

96. Seufert, V.; Ramankutty, N.; Foley, J.A. Comparing the yields of organic and conventional agriculture. Nature 2012, 485, 229. [CrossRef] [PubMed]

97. Godfray, H.C.J. The debate over sustainable intensification. Food Security 2015, 7, 199-208. [CrossRef]

98. Kremen, C.; Miles, A. Ecosystem Services in Biologically Diversified versus Conventional Farming Systems: Benefits, Externalities, and Trade-Offs. Ecol. Soc. 2012, 17, 40. [CrossRef]

99. Altieri, M.A. The ecological role of biodiversity in agroecosystems. Agric. Ecosyst. Environ. 1999, 74, $19-31$. [CrossRef]

100. Tscharntke, T.; Clough, Y.; Wanger, T.C.; Jackson, L.; Motzke, I.; Perfecto, I.; Vandermeer, J.; Whitbread, A. Global food security, biodiversity conservation and the future of agricultural intensification. Biol. Conserv. 2012, 151, 53-59. [CrossRef]

101. Duru, M. Combining agroecology and management science to design field tools under high agrosystem structural or process uncertainty: Lessons from two case studies of grassland management. Agric. Syst. 2013, 114, 84-94. [CrossRef]

102. Altieri, M.; Nicholls, C.I.; Henao, A.; Lana, M.A. Agroecology and the design of climate change-resilient farming systems. Agron. Sustain. Dev. 2015, 35, 869-890. [CrossRef]

103. Montagnini, F.; Nair, P.K.R. Carbon sequestration: An underexploited environmental benefit of agroforestry systems. Agrofor. Syst. 2004, 61, 281-295. [CrossRef]

104. Drinkwater, L.E.; Snapp, S.S. Nutrients in agroecosystems: Rethinking the management paradigm. Adv. Agron. 2007, 92, 163-186. [CrossRef]

105. Perfecto, I.; Vandermeer, J.; Philpott, S.M. Complex Ecological Interactions in the Coffee Agroecosystem. Annu. Rev. Ecol. Evol. Syst. 2014, 45, 137-158. [CrossRef]

106. Leyva, G.A.; Lores, P.A. Nuevos índices para evaluar la agrobiodiversidad. Agroecología 2012, 7, 109-115.

107. Vandermeer, J.H. The Ecology of Intercropping; Cambridge University Press: Cambridge, UK; New York, NY, USA, 1989.

108. Lovell, S.T.; DeSantis, S.; Nathan, C.A.; Olson, M.B.; Méndez, V.E.; Kominami, H.C.; Erickson, D.L.; Morris, K.S.; Morris, B. Integrating agroecology and landscape multifunctionality in Vermont: An evolving framework to evaluate the design of agroecosystems. Agric. Syst. 2010, 103, 327-341. [CrossRef] 
109. Nasielski, J.; Furze, J.; Tan, J.; Bargaz, A.; Thevathasan, N.V.; Isaac, M.E. Agroforestry promotes soybean yield stability and $\mathrm{N}_{2}$-fixation under water stress. Agron. Sustain. Dev. 2015, 35, 1541-1549. [CrossRef]

110. Thiel, B.; Smukler, S.M.; Krzic, M.; Gergel, S.; Terpsma, C. Using hedgerow biodiversity to enhance the carbon storage of farmland in the Fraser River delta of British Columbia. J. Soil Water Conserv. 2015, 70, 247-256. [CrossRef]

111. Woodgate, G.; Guzmán, E.S. Transformative agroecology: Foundations in agricultural practice, agrarian social thought and sociological theory. In Agroecology: A Transdisciplinary, Participatory and Action-Oriented Approach; Méndez, V.E., Bacon, C.M., Cohen, R., Gliessman, S.R., Eds.; CRC Press/Taylor \& Francis: Boca Raton, FL, USA, 2016; pp. 37-54.

112. Gonzalez de Molina, M. Political Agroecology: An essential tool to promote agrarian sustainability. In Agroecology: A Transdisciplinary, Participatory and Action-Oriented Approach; Méndez, V.E., Bacon, C.M., Cohen, R., Gliessman, S.R., Eds.; CRC Press/Taylor and Francis: Boca Raton, FL, USA, 2016; pp. 55-72.

113. DeLonge, M.S.; Miles, A.; Carlisle, L. Investing in the transition to sustainable agriculture. Environ. Sci. Policy 2016, 55, 266-273. [CrossRef]

114. Pimbert, M.P.; Moeller, N.I. Absent Agroecology Aid: On UK Agricultural Development Assistance Since 2010. Sustainability 2018, 10, 505. [CrossRef]

115. Brandt, S.A.; Thomas, A.G.; Olfert, O.O.; Leeson, J.Y.; Ulrich, D.; Weiss, R. Design, rationale and methodological considerations for a long term alternative cropping experiment in the Canadian plain region. Eur. J. Agron. 2010, 32, 73-79. [CrossRef]

116. Ministère de l'Agriculture, des Pêcheries et de l'Alimentation du Québec (MAPAQ). Stratégie de croissance du secteur biologique: Programme d'appui pour la conversion à l'agriculture biologique, 2015-2022. 2015. Available online: http:/ / www.mapaq.gouv.qc.ca/SiteCollectionDocuments/Formulaires / ProgrammeAppuiConversionbiologique.pdf (accessed on 21 September 2017).

117. Union Paysanne. Vers une Gestion de l'offre 2.0 au Canada: Document de Réflexion. Union Paysanne. (Also available in English as Toward Supply Management 2.0 in Canada: A Discussion Paper). 2014. Available online: www.unionpaysanne.com/gestion-de-1-offre-2-0 (accessed on 10 November 2017).

118. National Farmers Union (NFU). Strengthening Supply Management: Defending Canadian Control of Our Market Space and Advancing Food Sovereignty; Discussion Paper, January 2016; National Farmers Union: Saskatoon, SK, Canada, 2016.

119. Mount, P. Supply Management as Food Sovereignty. In Nourishing Communities: From Fractured Food Systems to Transformative Pathways; Knezevic, I., Blay-Palmer, A., Levkoe, C.Z., Mount, P., Nelson, E., Eds.; Springer: Cham, Switzerland, 2017; pp. 147-164.

120. People's Food Commission. The Land of Milk and Money: The National Report of the People's Food Commission; Between the Lines Publishing: Toronto, ON, Canada, 1980.

121. Levkoe, C.Z.; Sheedy, A. A people-centred approach to food policy making: Lessons from Canada's People's Food Policy project. J. Hunger Environ. Nutr. 2017, 21. [CrossRef]

122. People's Food Policy. Resetting the Table: A People's Food Policy for Canada. 2011. Available online: https: / / foodsecurecanada.org/people-food-policy (accessed on 21 September 2017).

123. Food Secure Canada (FSC). Building a Healthy, Just and Sustainable Food System: Food Secure Canada's Recommendations for a Food Policy for Canada. 2017. Available online: https: / / foodsecurecanada.org/sites / foodsecurecanada.org/files/attached_files/policy_brief_a_food_ policy_for_canada_sept_28_by_fsc.pdf (accessed on 21 September 2017).

124. Wezel, A.; Goette, J.; Lagneaux, E.; Passuello, G.; Reisman, E.; Rodier, C.; Turpin, G. Agroecology in Europe: Research, education, collective action networks, and alternative food systems. Sustainability 2018, 10, 1214. [CrossRef]

(C) 2018 by the authors. Licensee MDPI, Basel, Switzerland. This article is an open access article distributed under the terms and conditions of the Creative Commons Attribution (CC BY) license (http:/ / creativecommons.org/licenses/by/4.0/). 